\title{
AUTOMATION SYSTEM FOR A SMALL POULTRY FARM USING A PSOC5LP
}

\author{
YELI K. GALEANO M, JULIÁN R. CAMARGO L \& MIGUEL A. ÁVILA A
}

Engineering Faculty, Universidad Distrital Francisco José de Caldas, Bogotá, Colombia

\begin{abstract}
This article presents the design and implementation of an automation system for a poultry farm, making the process of feeding, care, air conditioning and development of the animals more controlled, precise and effective, improving the process of raising broilers to obtain a balance between quality and quantity of production. At the same time, data of multiple physical variables were collected during the time of breeding of the birds, which later allowed carrying out detailed studies of the farm's environment.
\end{abstract}

KEYWORDS: Automation, Production, PSoC5LP, Relative Humidity, Temperature

Received: Jun 08, 2020; Accepted: Jun 28, 2020; Published: Sep 12, 2020; Paper Id.: IJMPERDJUN20201184

\section{INTRODUCTION}

Currently, the poultry sector in Colombia aims to move business for 17.5 billion pesos in 2017, half a billion more than in 2016. The president of the National Federation of Poultry Farmers (Fenavi), estimated that the production of chicken meat will grow about $5.2 \%$, he also added that in 2016 there were 800 million birds in the poultry houses, among those for fattening and laying, by 2017 it is expected that the production will exceed 1.5 million tons of meat for the first time. Thus, today chicken participates with $47 \%$ of the 67 kilos of protein consumed by a Colombian in the year [1].

Poultry farms in Colombia, whether they are broilers, laying hens or breeders, are becoming increasingly automated. This process has taken approximately 15 years, automation is reaching 8 floors, similar to what happens in other parts of the world. The reason why this change is taking place in the Colombian poultry industry is due to the efficiency of the products produced by the automatic equipment, in addition to the savings in consumption and waste of feed, the controls they provide and the uniformity of the birds [2]. These implementations are only benefiting large producers and are implemented with very expensive equipment and very advanced technology.

The most appropriate social, economic and cultural strategy to maintain the well-being of communities is as the Food and Agriculture Organization of the United Nations refers to livestock production systems, arguing that it is an activity that can, among other things, provide daily livelihood security, conserve ecosystems and satisfy cultural and traditional values. Also, the organization states that the livestock sector in Latin America has grown significantly over the years, with the greatest demand for poultry meat. We can see this in small-scale poultry production, which under management policies and specific investments that strengthen its productive and social role and also allow it to be a sustainable process, an activity that can provide economic support [3].

Small-scale livestock production generates a significant portion of the food needed for a country's domestic market, since it contributes significantly to national development, among other things. The Food and 
Agriculture Organization of the United Nations states that in Colombia, small producers represent $80.7 \%$ of the total land area at the national level, and with this percentage, we can get an idea of the number of people who can benefit from process automation, since for their development they require not only timely animal health and veterinary services and technical assistance, but also access to better and new technologies and innovation in production systems that guarantee sustainability, access to markets and or improve the contribution of self-consumption.

\section{POULTRY PRODUCTION AND TECHNOLOGY}

During the last decade, many developing countries have adopted intensive poultry production to meet the demand for animal protein. In recent years, the poultry subsector has become increasingly important in national GDP. Also, it has been consolidated as a line of the economy that generates high direct and indirect employment, accompanied by important technological progress and offers the country a protein food source, which, consequently, contributes to the nutrition of Colombians.

\subsection{Poultry production in the World}

World production of chicken meat could well exceed 100 million tons in 2016, of which America is likely to contribute some 44.3 million tons or $44 \%$. Data provided by the USDA (United States Department of Agriculture) specifically on broiler production, point to a 3.4 percent annual growth in world production, with production rising from 63.1 million tons in 2005 to an estimated 87.9 million tons this year, while in 2016 it is expected to exceed 89 million tons (Figure 1) [4], $[5]$.

\begin{tabular}{|l|r|r|r|r|r|r|r|r|r|r|r|r|r|r|r|r|}
\hline Region & $\mathbf{2 0 0 0}$ & $\mathbf{2 0 0 5}$ & $\mathbf{2 0 0 6}$ & $\mathbf{2 0 0 7}$ & $\mathbf{2 0 0 8}$ & $\mathbf{2 0 0 9}$ & $\mathbf{2 0 1 0}$ & $\mathbf{2 0 1 1}$ & $\mathbf{2 0 1 2}$ & $\mathbf{2 0 1 3}$ & $\mathbf{2 0 1 4 E}$ & $\mathbf{2 0 1 5 P}$ & $\mathbf{2 0 1 6 P}$ \\
\hline Africa & 2.8 & 3.3 & 3.4 & 3.7 & 4.0 & 4.2 & 4.5 & 4.5 & 4.6 & 4.7 & 4.9 & 4.9 & 4.9 \\
\hline America & 27.1 & 32.7 & 33.7 & 35.0 & 37.5 & 36.9 & 38.8 & 40.0 & 40.5 & 42.1 & 42.8 & 43.4 & 44.3 \\
\hline Asia & 18.6 & 22.4 & 23.5 & 25.0 & 26.2 & 28.0 & 29.2 & 30.3 & 31.6 & 32.2 & 32.1 & 32.7 & 33.1 \\
\hline Europe & 9.5 & 10.9 & 10.8 & 11.6 & 12.1 & 13.3 & 13.9 & 14.6 & 15.5 & 16.1 & 16.5 & 16.7 & 17.0 \\
\hline Oceania & 0.7 & 0.9 & 1.0 & 1.0 & 1.0 & 1.0 & 1.1 & 1.2 & 1.2 & 1.3 & 1.2 & 1.3 & 1.3 \\
\hline WORLD & $\mathbf{5 8 . 7}$ & $\mathbf{7 0 . 3}$ & $\mathbf{7 2 . 3}$ & $\mathbf{7 6 . 2}$ & $\mathbf{8 0 . 7}$ & $\mathbf{8 3 . 4}$ & $\mathbf{8 7 . 4}$ & $\mathbf{9 0 . 6}$ & $\mathbf{9 3 . 3}$ & $\mathbf{9 6 . 3}$ & $\mathbf{9 7 . 5}$ & $\mathbf{9 9 . 0}$ & $\mathbf{1 0 0 . 6}$ \\
\hline & & & & & & & & & & & \\
\hline
\end{tabular}

Figure 1: World production of chicken meat (millions of tons) [4]

\subsection{Poultry production in Latin America}

According to the article published in mid-2016 by the portal the poultry site "World Poultry Trends 2016: America represents 44 percent of world chicken production. In all countries of the Americas, chicken meat production has grown $3.5 \%$ annually between 2000 and 2013. Having as main producer the United States with 17.6 million tons in 2013, with an annual growth rate of less than $2 \%$. In contrast, Brazil's industry in this same year had an annual growth rate of $6 \%$ during the same period (Figure 2).

\begin{tabular}{|l|r|r|r|r|r|r|r|r|r|r|r|r|r|}
\hline Country & $\mathbf{2 0 0 0}$ & $\mathbf{2 0 0 5}$ & $\mathbf{2 0 0 6}$ & $\mathbf{2 0 0 7}$ & $\mathbf{2 0 0 8}$ & $\mathbf{2 0 0 9}$ & $\mathbf{2 0 1 0}$ & $\mathbf{2 0 1 1}$ & $\mathbf{2 0 1 2}$ & $\mathbf{2 0 1 3}$ & $\mathbf{2 0 1 4}$ & $\mathbf{2 0 1 5 P}$ & $\mathbf{2 0 1 6 P}$ \\
\hline EUA & 13,703 & 15,870 & 15,930 & 16,226 & 16,561 & 15,935 & 16,563 & 16,694 & 16,621 & 16,976 & 17,299 & 17,966 & 18,365 \\
\hline Brasil & 5,980 & 9,350 & 9,355 & 10,305 & 11,033 & 11,023 & 12,312 & 12,863 & 12,645 & 12,308 & 12,692 & 13,080 & 13,480 \\
\hline México & 1,936 & 2,498 & 2,592 & 2,683 & 2,853 & 2,781 & 2,822 & 2,906 & 2,958 & 2,907 & 3,025 & 3,100 & 3,160 \\
\hline Argentina & 870 & 1,030 & 1,200 & 1,320 & 1,435 & 1,500 & 1,680 & 1,770 & 2,014 & 2,060 & 2,050 & 2,060 & 2,100 \\
\hline
\end{tabular}

Figure 2: Main producers of broiler meat in America (tons gutted weight) [4] 
Data provided by the USDA on broiler production reflects that in 2016 in the United States and Brazil the estimated production in tons of meat will increase significantly, while little change is expected in terms of production levels in Mexico and Argentina. For other major producers such as Peru and Colombia, production will remain stable [4].

\subsection{Poultry Production in Colombia}

Thanks to the joint work of Fenavi-Fonav, the Ministry of Agriculture and DANE, which in 2002 carried out the first national census of industrial poultry farming, the country has statistical information on this sector for the first time. This document states that for that period "In Colombia there are 2,996 commercial poultry farms, of which 1,870 are dedicated to chicken fattening"[6].

The map in Figure 3 below shows the geographic location of poultry farms and facilities by the production system. In this map, we can see that in the Orinoquia region and the Amazon region no type of poultry production is reflected [7].

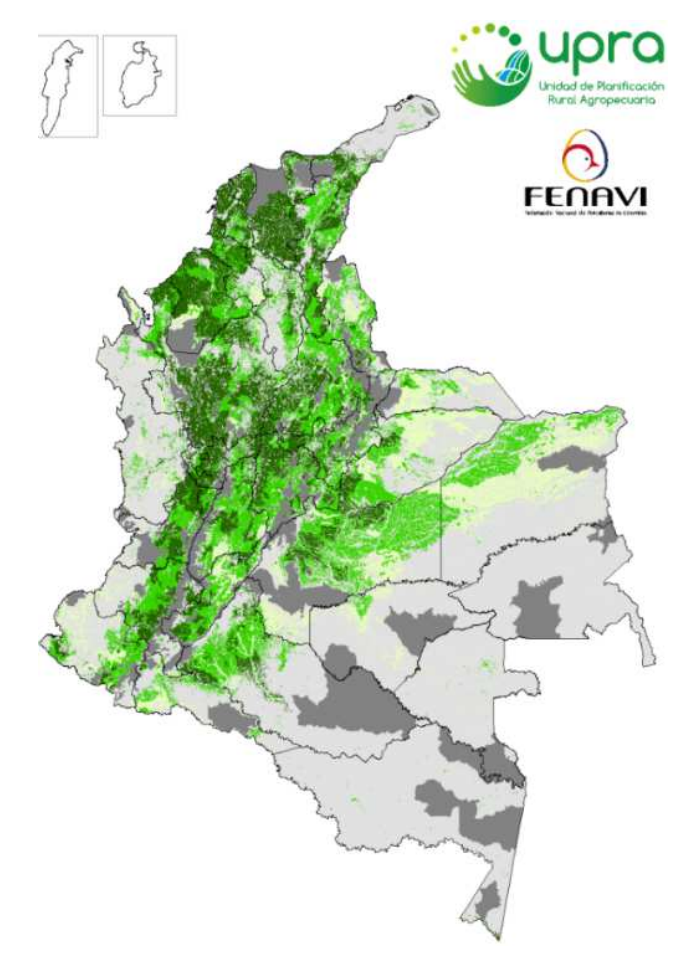

Figure 3: Geographic location of chicken farms in Colombia [7]

According to the farm registry reported by FENAVI on its official website, there are 3,366 farms in the country with a capacity to accommodate $97,193,789$ fattening birds. Of the total number of existing chicken farms, Cundinamarca has 803, followed by Santander (648), Valle del Cauca (379) and Nariño (199). The remaining 1,337 farms are distributed throughout the other departments [8].

\subsection{The technology used to provide food, water and environmental control}

\subsubsection{Feeding system}

In the poultry industry-oriented to large producers, different suppliers are implementing automatic feeders. Figure 5 shows a general description of the components of this mechanism; it can be said that this implementation meets the feeding needs of chickens of any age, ensuring the best conversion with less investment and is state-of-the-art technology [9]. 
Broadly speaking, this mechanism seeks to dose the birds' feed, depending on the growth stage they are in. To this end, it has a hopper that allows storing large amounts of feed; the line motor distributes the necessary feed to each plate and the portion is measured using proximity sensors to detect when the machine should stop (Figure 4).

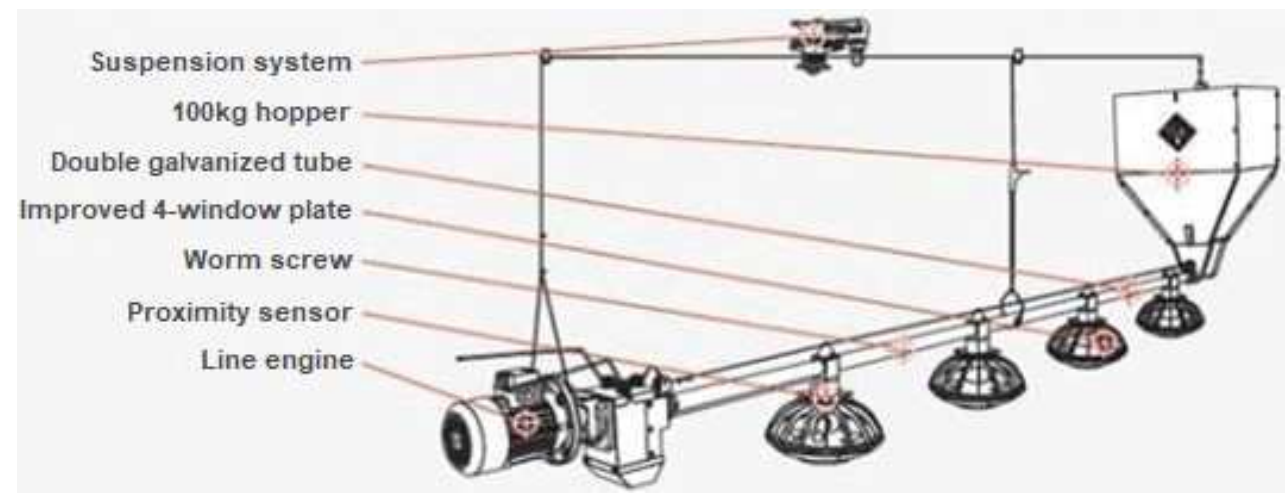

Figure 4: Broilermatic Automatic Feeder [10]

\subsubsection{Drinking system}

The industry is implementing the lines of nipple drinkers because they have advantages such as minimum water waste, low humidity and therefore less ammonia, better water temperature, among others. The suppliers handle a great diversity of technologies and mechanisms, but most of them have a pressure reducer so that the water flows in the correct way inside the system and at the same time the consumption of the liquid can be sensed. The filtered water is directed by a piping system to the pressure reducer of each line of drinkers, after lowering the pressure it is distributed and the birds have the precious liquid available in a constant and timely manner. Figure 5 shows the drinking system proposed by IMPEX, a company recognized for its high-quality standards within the poultry industry [11].
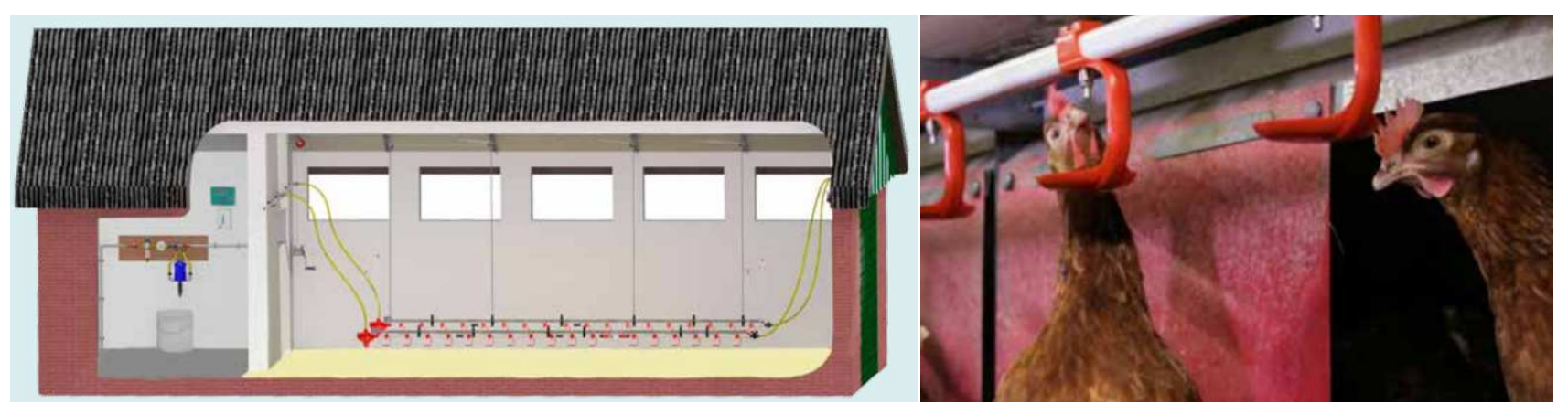

Figure 5: MPEX Closed Drinking System [11]

\subsubsection{Ventilation system}

Because ventilation can provide an optimal environment within the broiler house, an understanding of the basic principles of ventilation is essential for proper house design and management [12]. There are two basic types of ventilation systems:

- Natural Ventilation: Also known as open, or curtained, or natural, fans can be used inside the shed to circulate and move the air.

- Forced Ventilation (controlled environment or closed sheds): Normally these sheds have solid walls or curtains that are kept closed during the operation of the shed. Fans and air inlets are used to ventilate the house.

For each of these types of ventilation, different technologies are implemented which, as mentioned before, are 
very costly and require practically the restructuring of the warehouse in general, due to their rigorous handling and operating conditions. The technologies used and the control system depends on the supplier, but most of these implementations are made through a programmable logic controller (PLC), which allows any type of industrial automation [13].

\section{THE SELECTED POULTRY FARM}

\subsection{The Geographical Location of the Poultry Farm}

This research is intended to benefit small producers of poultry plants, for this reason, it was decided to take the municipality of Nemocón (Cundinamarca) as the epicenter. This municipality is part of the Province of Sabana Centro, 45 $\mathrm{km}$ from the city of Bogotá D.C. (Colombia), most of the territory has a cold climate with an average annual temperature of $12.8{ }^{\circ} \mathrm{C}$. It is necessary to talk about the climatic conditions of the place because it is the main factor that influences the type or style of the sheds and at the same time the amount of production population that, due to factors like this may not be the desired one.

\subsection{Characteristics of the Automated Shed}

The broiler management guidelines show the critical factors that directly affect the performance of a flock [14], to achieve the correct cost/benefit ratio, durability and adaptation to provide a controllable environment, and then list the steps followed for the correct implementation of the flock:

- For the construction of a broiler house, initially, a well-drained land with sufficient natural airflow is selected. The house should be oriented on an east-west axis to reduce the amount of direct sunlight on the sidewalls during the hottest hours of the day and should have a sturdy physical structure to support the installation of the automation system.

- A roof is installed whose material has a reflective surface on the outside to lower the conduction of solar energy. Additionally, the roof should be insulated [14].

- Wooden structures are installed as support for the ventilation curtains and the mechanisms of the feeders and drinkers.

The manufactured house has an area of $4 \mathrm{~m} 2$, with this information the population density is calculated (amount of birds that can be bred in a square meter), for each one of the consulted authors there are many ways to determine this factor, in this case, the technologist in the breeding of fattening chickens was consulted, author of the Avipunta technical manual, Table 1 shows what he says about this issue, in which you can see the age at which the house should be expanded, expressed in days of rearing, and the number of birds that should be kept per square meter [15].

Table 1: Population density management data [15]

\begin{tabular}{|l|l|l|}
\hline $\begin{array}{l}\text { Age } \\
\text { Days }\end{array}$ & $\begin{array}{l}\text { Chickens } \\
\mathbf{m}^{\mathbf{2}}\end{array}$ & Management \\
\hline 1 & 30 & Starting up \\
\hline 4 & 25 & Enlarge \\
\hline 10 & 20 & Enlarge \\
\hline 16 & 15 & Enlarge \\
\hline
\end{tabular}




\begin{tabular}{|l|l|l|}
\hline 21 & 10 & Until sale \\
\hline
\end{tabular}

Making use of this information, it is necessary to have a maximum of 40 birds for an area of $4 \mathrm{~m} 2$, but taking into account that the mechanisms of the drinkers and feeders will occupy space inside the house, it is considered pertinent to have 30 birds for breeding. Figure 6 shows the final structure of the house where the implementation of all the equipment began.

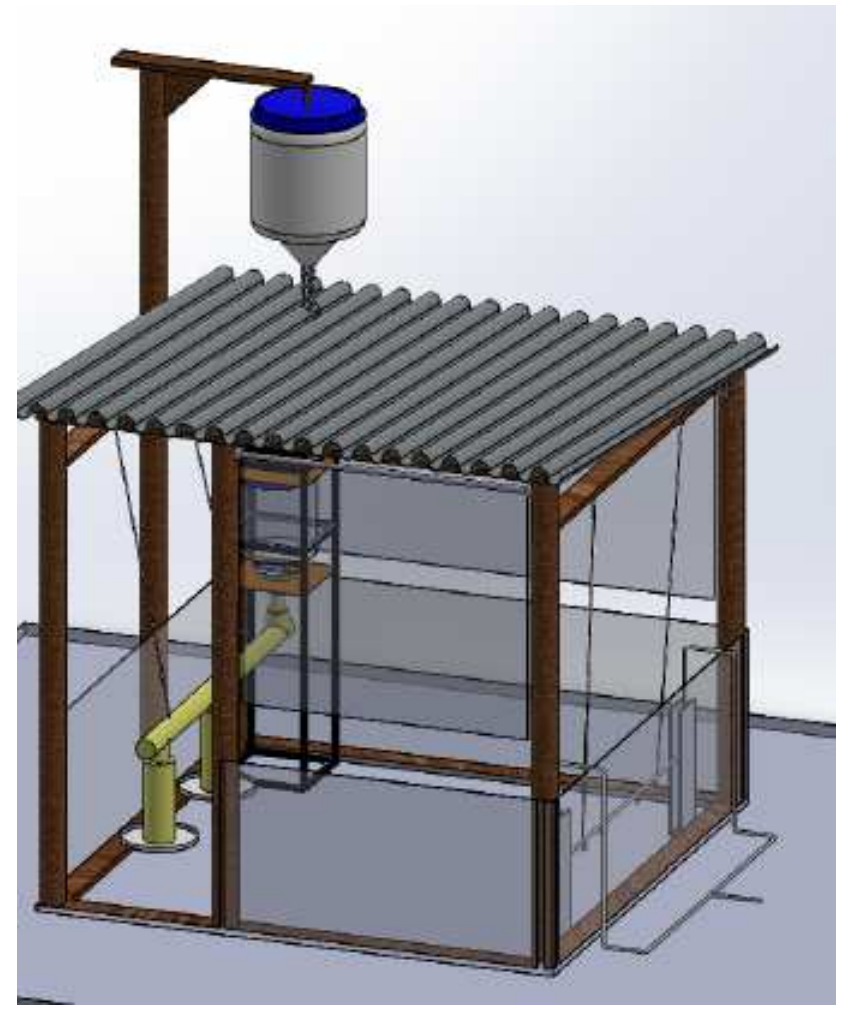

Figure 6: Rendered structure of the manufactured poultry house

\subsubsection{Ventilation System Implemented}

Based on the idea already raised of natural ventilation or open poultry house, in Figure 7 you can see the installation of the mechanism of each of the curtains.

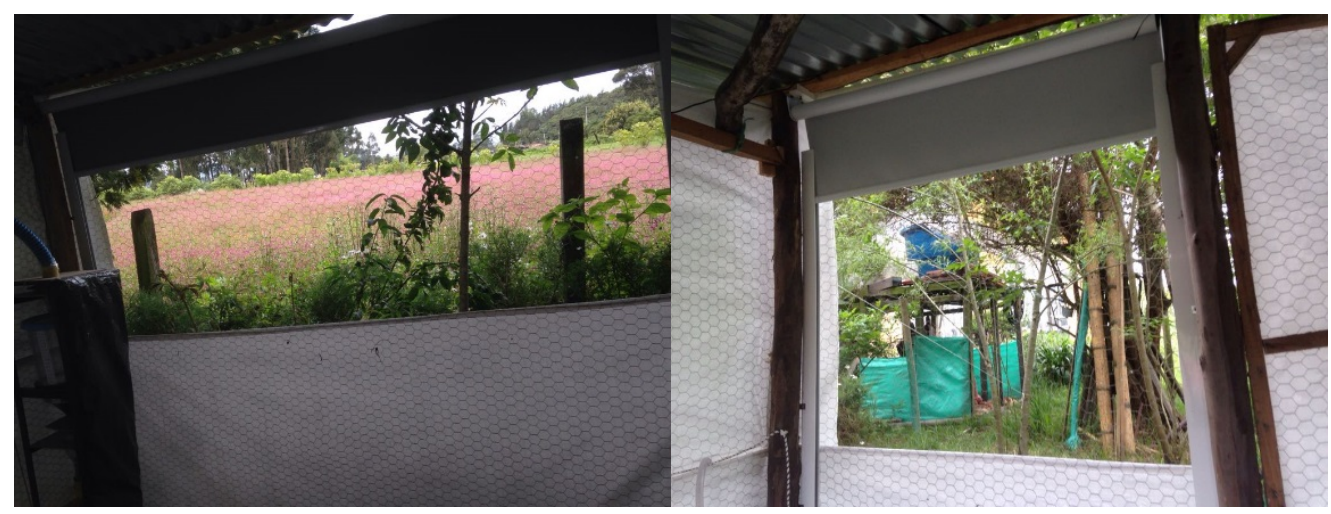

Figure 7: Curtain mechanism installed on the rear and front wall of the poultry house 


\subsubsection{Trough System Implemented}

The concentrated feed and the corn in the appropriate portions are obtained from this hopper and fall into the hopper which calculates the indicated portion depending on the age of the bird with the help of a distance sensor, the passage of the feed is possible thanks to the activation of a gate. The hopper that stores the portions has a capacity of $8 \mathrm{~kg}$ and was characterized by weight, and so the control algorithm programmed the distances at which the indicated portion was completed, according to what is shown in Figure 8 (Right).

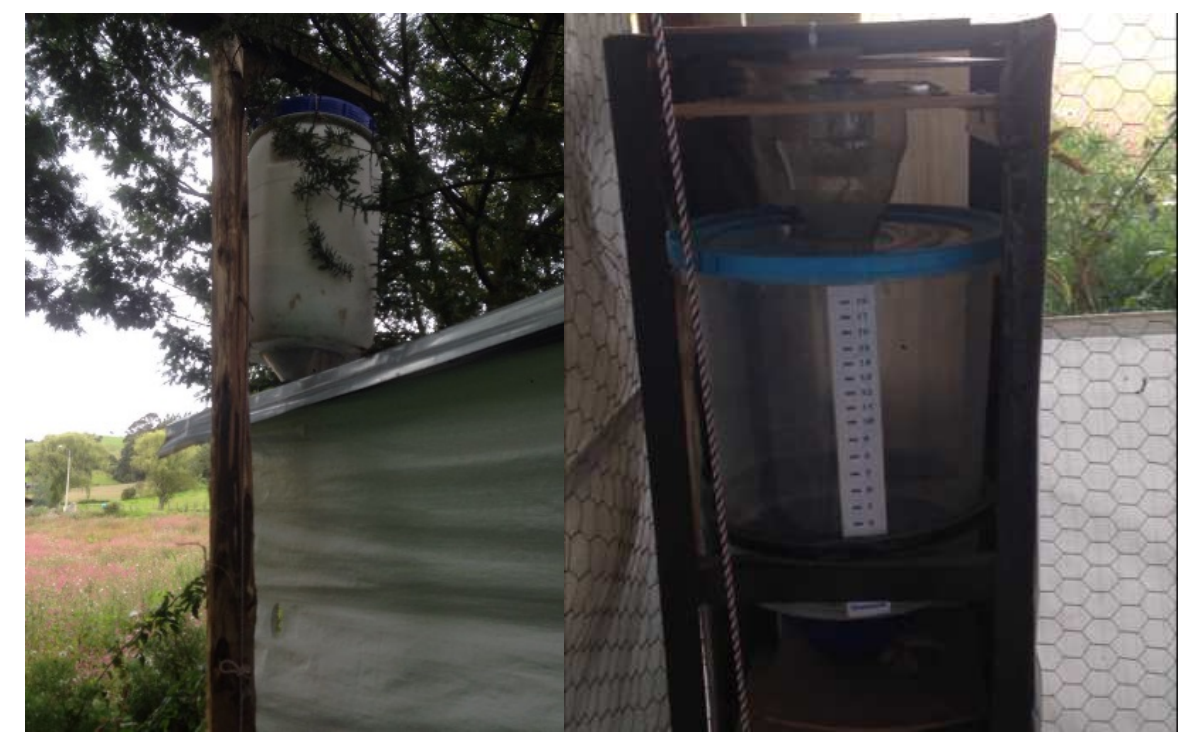

Figure 8: Hoppers designed for food storage: (Left) storage hopper, (Right) portion hopper

The outlet of the portion hopper is directly connected to the mechanism made of PVC tube, which, using an endless screw, dispenses the food in hanging platter feeders, where the birds have access and can ingest the food (Figure 9). The worm is made of galvanized wire to prevent it from rusting and causing any type of health problem.

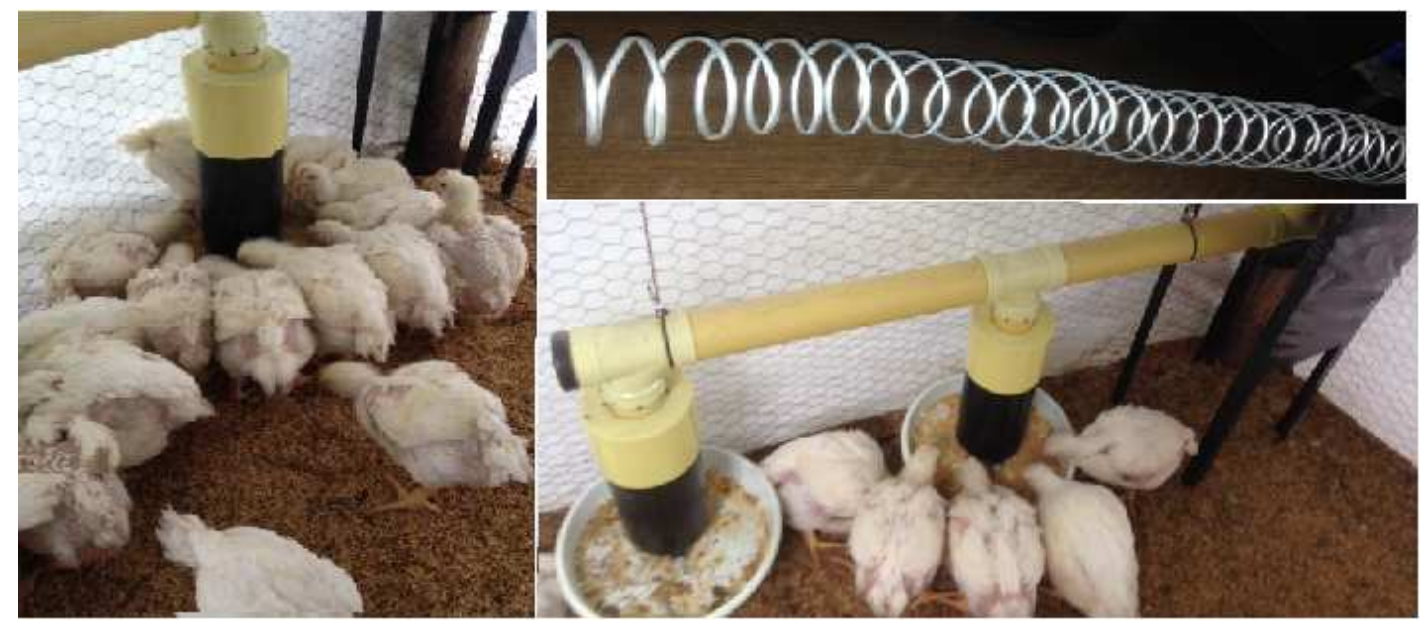

Figure 9: Structure of the hanging platter feeders

\subsubsection{Drinking system implemented}

The drinkers were installed in a half-inch PVC pipe, designed for the transport and storage of drinking water. A waterproof wooden base was designed to prevent the structure from swinging and ensure that the birds have no problem accessing this 
system. Figure 10 shows the mechanism installed inside the poultry house. It is possible to observe the motor that, with the help of a reel, allows the pulling of the ropes that hold the pipe and manages to modify the height of the pipe and the buttons that activate the system. It is worth mentioning that the height of this system is modified by the person who takes care of the birds depending on the age of the bird. It is also important to mention that the water is obtained from a storage tank and reaches the drinking troughs thanks to gravity.

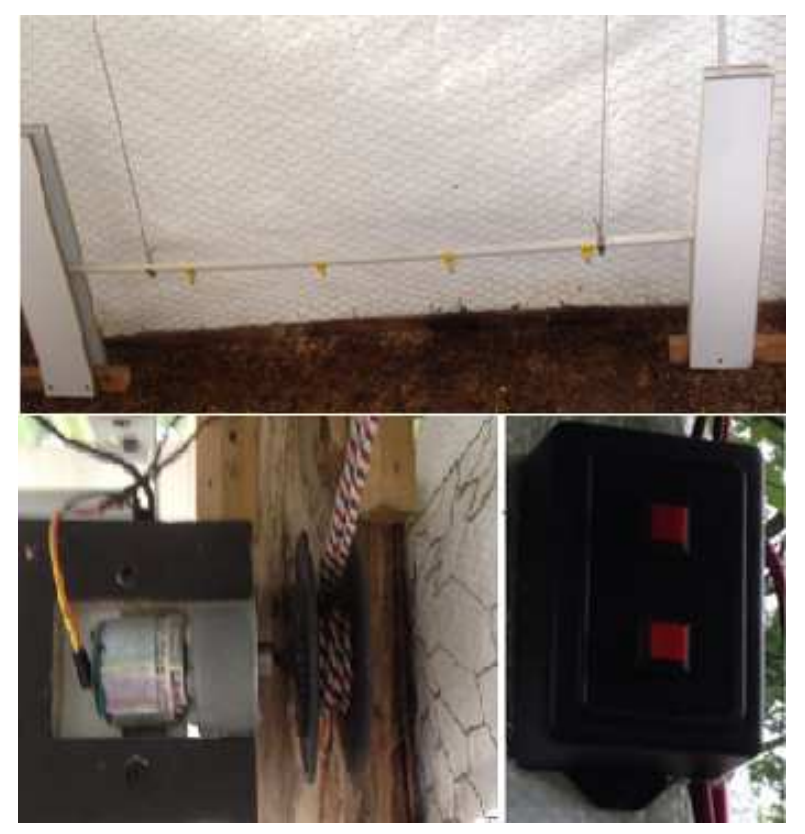

Figure 10: Components of the drinking system installed inside the poultry house

\section{METHODOLOGY}

Figure 11 shows the block diagram of the implemented automation system. The heart of the system is a PSoC5LP which is a system that offers innovative capabilities integrated into a single chip, manufactured by the American company Cypress Semiconductor, with a modern acquisition method, signal processing and control and excellent accuracy, including a set of digital (UDB) and analog blocks that make the PSoC a very good proposal for the development of engineering projects, giving the system the ability to assign any function to any terminal of the integrated circuit, which gives it great versatility [16], [17]. 


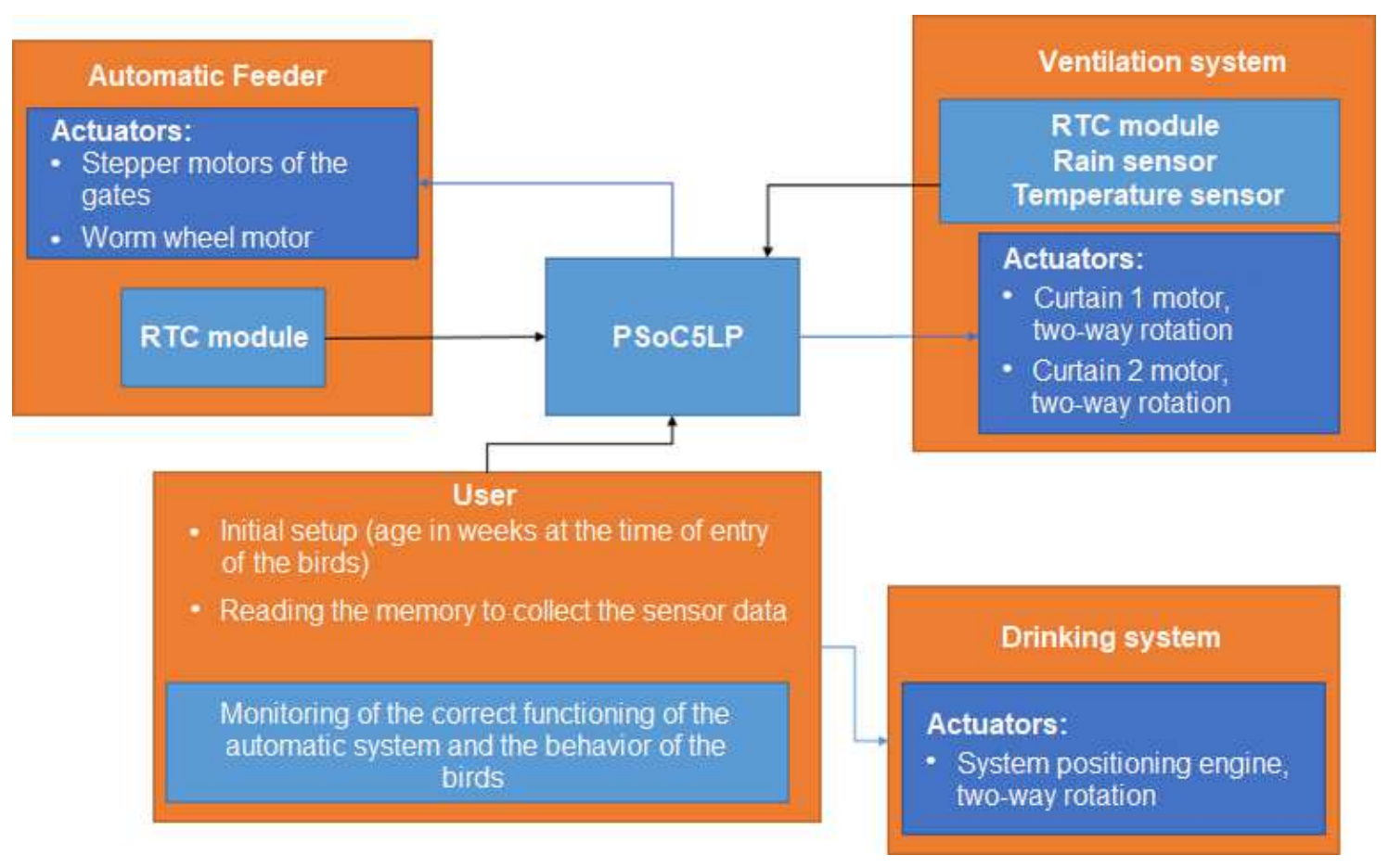

Figure 11: Block diagram of the implemented system

\subsection{Design of the House Ventilation System}

Ventilation is the main way to control the birds' environment. Through it, an acceptable quality of air is maintained in the poultry house by keeping the birds in comfortable temperature conditions. Ventilation also provides fresh air, removes excess moisture and limits the buildup of gases and airborne byproducts that can be harmful.

In this case, the type of ventilation that best meets the desired requirements is natural ventilation, firstly because of the environmental conditions of the installation site that lend themselves to this type of ventilation and secondly because of the size of the house and the population density of the house. It is the simplest type of ventilation to implement, corresponding to an open poultry house on the sides that has curtains that can be opened to allow the outside breeze and internal convection currents to make the airflow into and along with the poultry house (Figure 12). For this reason, the main activity of this phase was the installation of the curtains following the key design requirements for this [12].
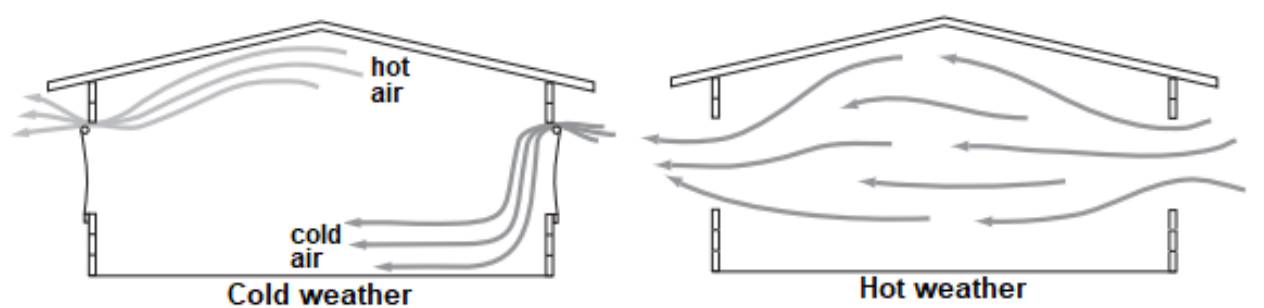

Figure 12: Natural ventilation (with curtains) [12]

The control of the position of the curtains is very important to maintain an adequate room temperature inside the poultry house and to avoid draughts, both during the day and at night, especially during the first 4 weeks of the birds' life. As the bird grows, the external curtains are lowered, and from week 5 onwards the curtain can remain completely open during the day, but depending on the average temperature of the place, it must be considered to close them at night [18]. 
Figure 13 shows each of the states of the curtains for the three conditions of the control system implemented in the PSoC5LP, which depends on three devices: RTC, rain sensor and temperature and humidity sensor.
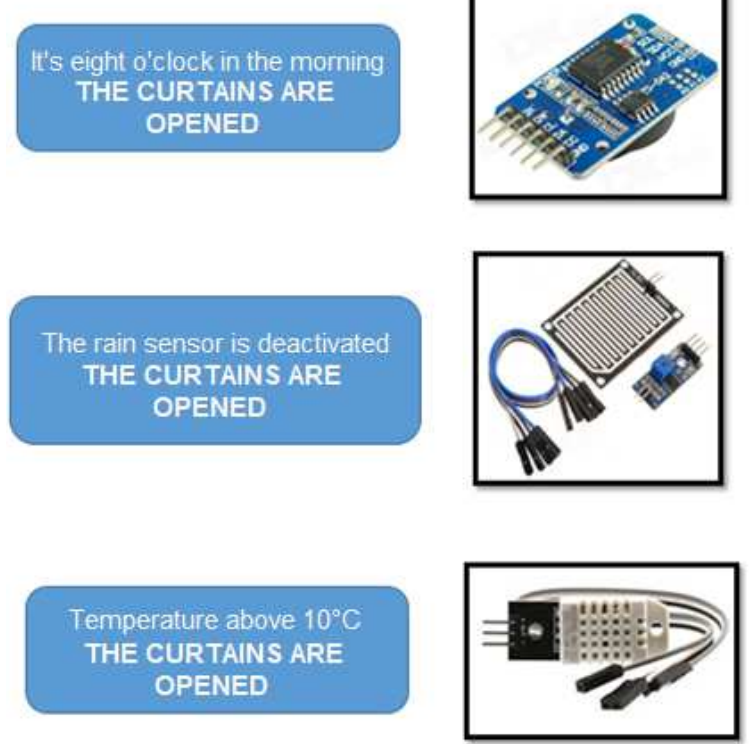

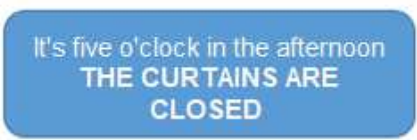
CLOSED

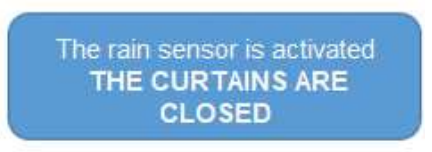

Temperature below $10^{\circ} \mathrm{C}$

THE CURTAINS ARE CLOSED

Figure 13: Curtain states for the three conditions of the control system

\subsection{Design of the Shed's Trough System}

The recommendations of the broiler management guide are taken into account for this topic. One of the most relevant points is the space that must be provided to the birds for their feeding since if this is insufficient the growth rate will be reduced and the uniformity of the flock will be severely compromised, regardless of the type of feeders used. All feeders must allow for the storage and distribution of feed with the minimum waste and with the volume of feed indicated for each stage of the bird's growth, taking into account the type of feed provided in each one of them. It is also recommended to provide a $33 \mathrm{~cm}$ plate for every $50-70$ birds [19].

To design the mechanism of the feeders, the diet and the portions that should be administered to the birds were proposed (Table 2). In this case, the birds arrive at three weeks of age, it must be taken into account that there are 30 birds in the house and that two portions of food are provided daily. In the poultry house, the birds remain 4 weeks, during these weeks two types of feed are used (initiation and fattening) and crushed corn.

Table 2: Food portions according to the age of the bird

\begin{tabular}{|l|l|l|l|}
\hline Age in weeks & Portion of food & Portion of corn & Total \\
\hline Week 4 & 2.25 pounds (initiation) & 1.25 pounds & 3.5 pounds \\
\hline Week 5 & 3 pounds (initiation) & 1.25 pounds & 4.25 pounds \\
\hline Week 6 & 3 pounds (initiation) & 1.875 pounds & 4.875 pounds \\
\hline Week 7 & 3 pounds (fattening) & 2.5 pounds & 5.5 pounds \\
\hline
\end{tabular}

The automatic hanging feeder is made up of a series of hoppers (Figure 14), each one of which has a gate that is controlled using step motors and an endless screw (in charge of feeding the feeders) which is directed by a direct current motor. 


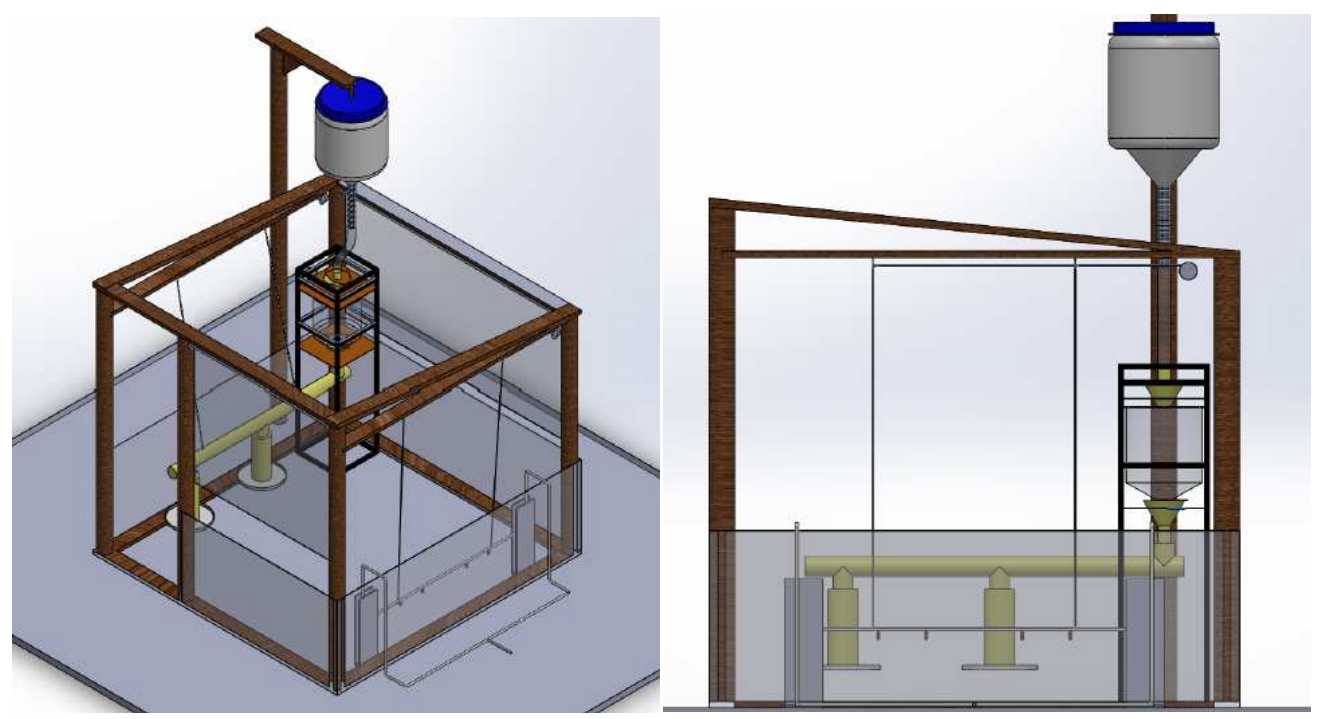

Figure 14: View of the mechanism designed to provide the food

Making use of the RTC that is also used by the ventilation system, two fixed schedules are chosen to generate the filling of the feeders, for this an ultrasound sensor is used to determine the amount of food in the hopper 2 (hopper 1 is used for the storage of all the food), according to the age making use of the information of Table 2, after having the adequate portion this is distributed in each one of the feeders activating the motor of the endless screw. In Figure 15 you can see the algorithm implemented in the PSoC5LP to perform the task of controlling the system filling the troughs.

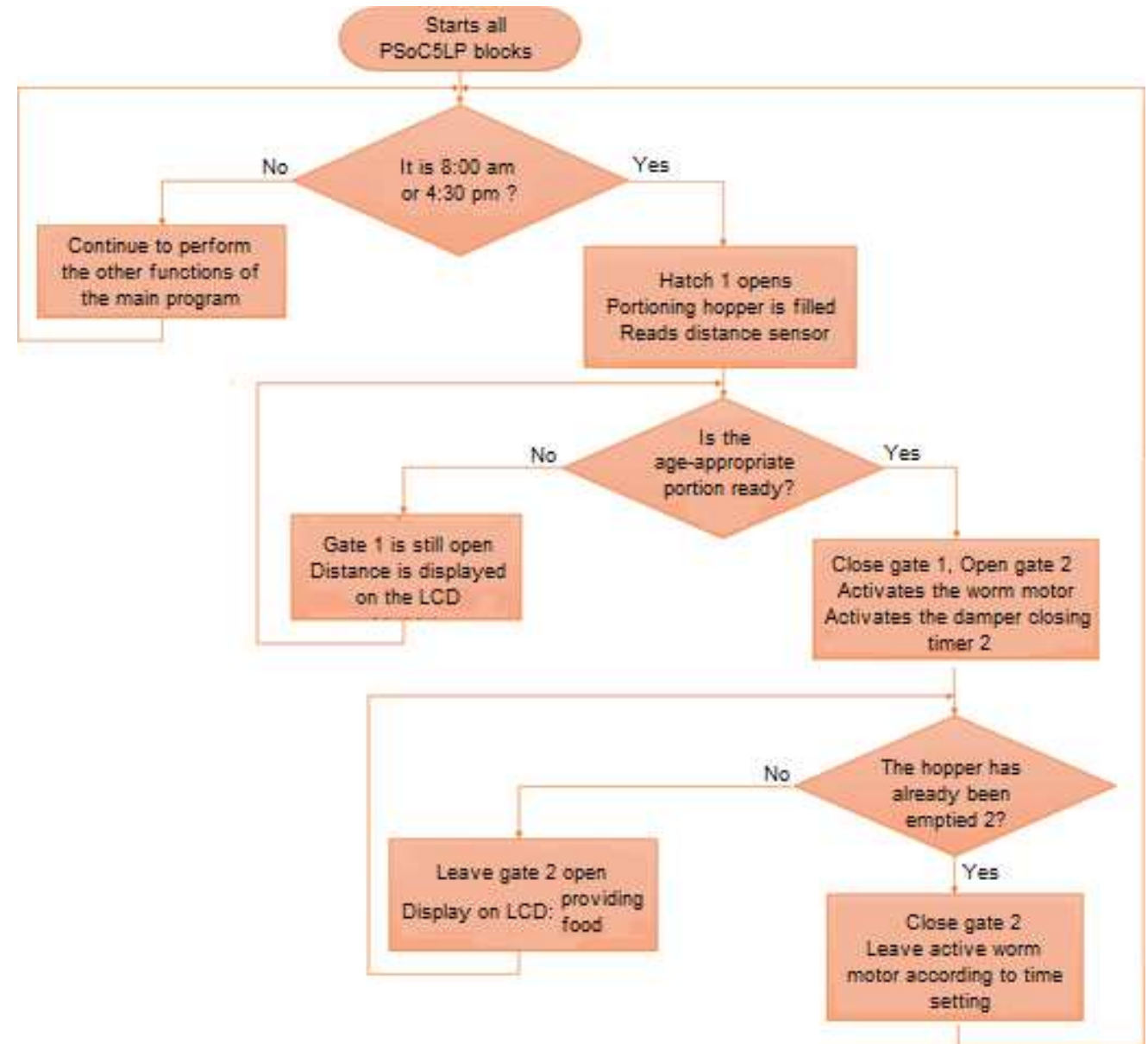

Figure 15: Flowchart of the operation of the system designed for the trough 


\subsection{Design of the house drinking system}

For the installation of closed system drinkers, the recommendations of the broiler handling guide are again taken into account. These nipple drinkers are widely used since they present advantages such as reducing the spread of diseases, providing clean water and reducing the requirements of cleaning personnel. The following factors were taken into account for their implementation:

- Acquire nipple drinkers, according to the density of the flock it is estimated how many are required inside the house (10 birds per drinker).

- Install the piping system that is the water supply route. In this phase, the water pressure and the location of the pipes must be taken into account.

- Take into account the height of the water supply pipe (the birds must raise their heads to reach the nipple, so it must be higher than the birds' backs to avoid collisions between the birds and loss of water as shown in Figure 16). For this reason, it is necessary to implement a mechanism that allows me to control the height of the drinkers depending on the growth stage of the flock.
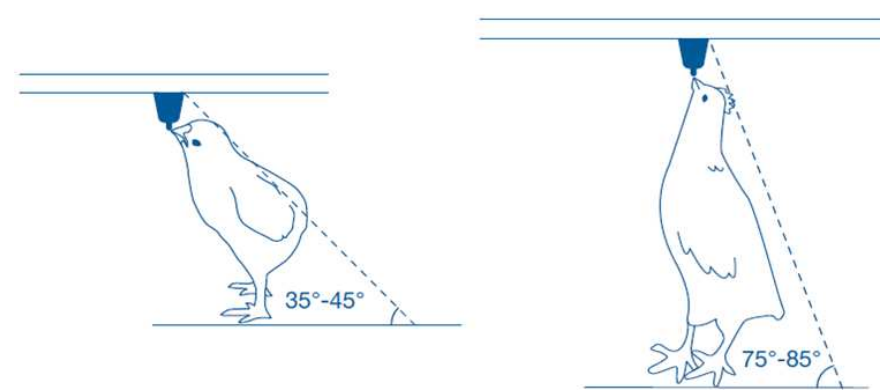

Figure 16: Adjusting the height of the drinkers depending on the stage of growth of the bird [20]

The idea is that taking into account the calculated flock density and following the broiler management guide [21] one nipple is required for every 10 birds so 4 nipples were installed (Figure 17). Half inch PVC pipe and a pair of hoses were used to adapt the system to the different heights required.

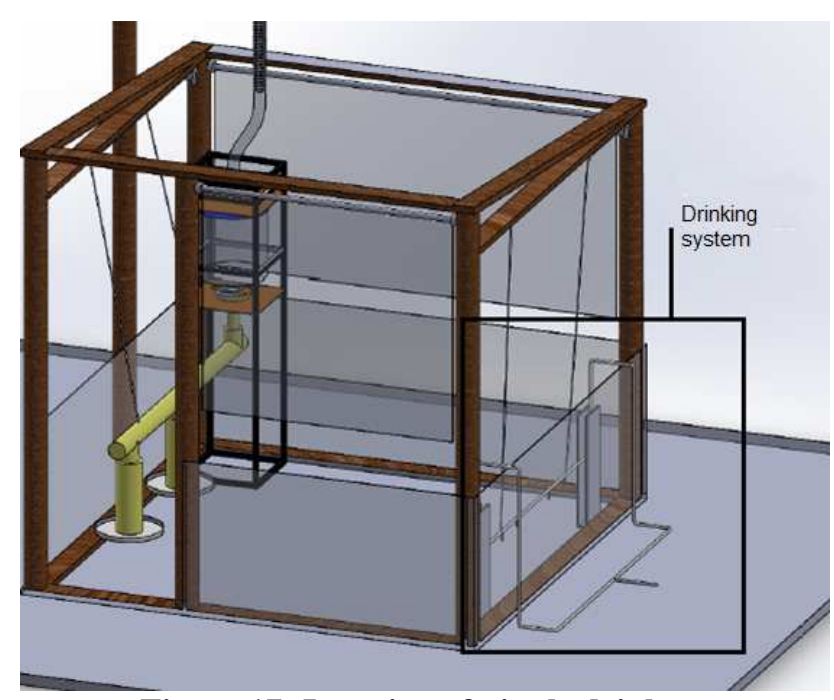

Figure 17: Location of nipple drinkers

To be able to vary the height of the drinkers, a mechanical system was used with two pulleys to support the weight of the tube where the nipples were installed, a 12-volt direct current motor and a reel that allows the system to be raised or 
lowered. To reverse the rotation of the motor, an H-bridge was mounted and two buttons allow the system to be operated manually.

\section{RESULTS}

\subsection{Analysis of Physical Variables}

After the installation of the system, data on physical variables are taken to monitor the environment inside the poultry house. The measurement taken by the DHT22 temperature and humidity sensor used is compared with a commercial thermo-hygrometer. The thermo-hygrometer used was the HTC-1 with calibration certification, among its functions are: indoor temperature indicator, indoor humidity indicator, changeable temperature unit $(\square / \square)$, memory function, MAX/MIN store temperature and humidity values, 2-time display modes: $12 \mathrm{~h} / 24 \mathrm{~h}$, among others [22].

Data were collected from day 21 to the end of day 48 of the birds' lives, initially a one-day test was done to analyze its reliability and to be sure that the monitoring data was accurate. Figure 18 and Figure 19 show both temperature and relative humidity data collected over 12 hours.

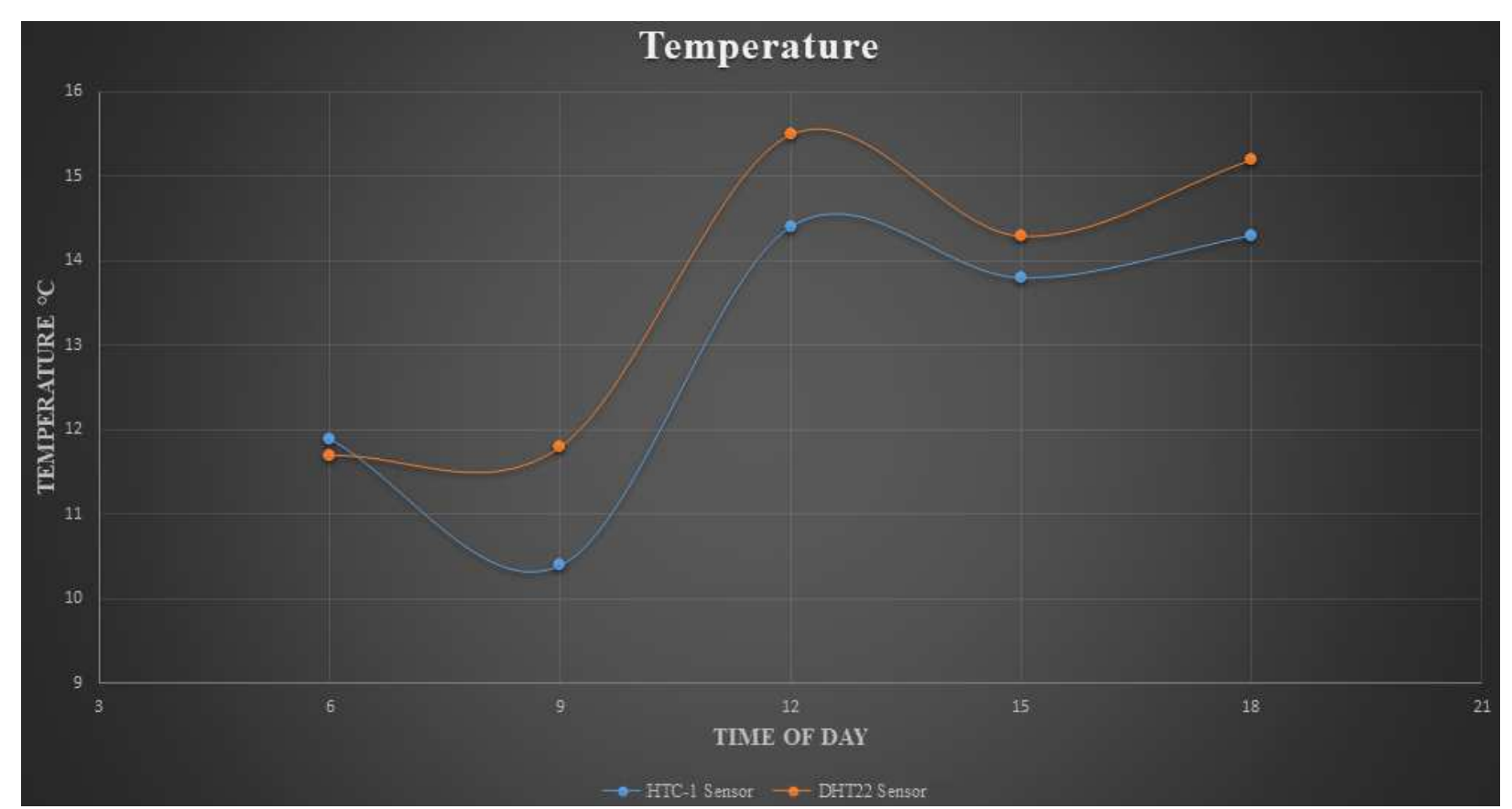

Figure 18: Comparison of temperature data with commercial sensor and sensor used in the application 


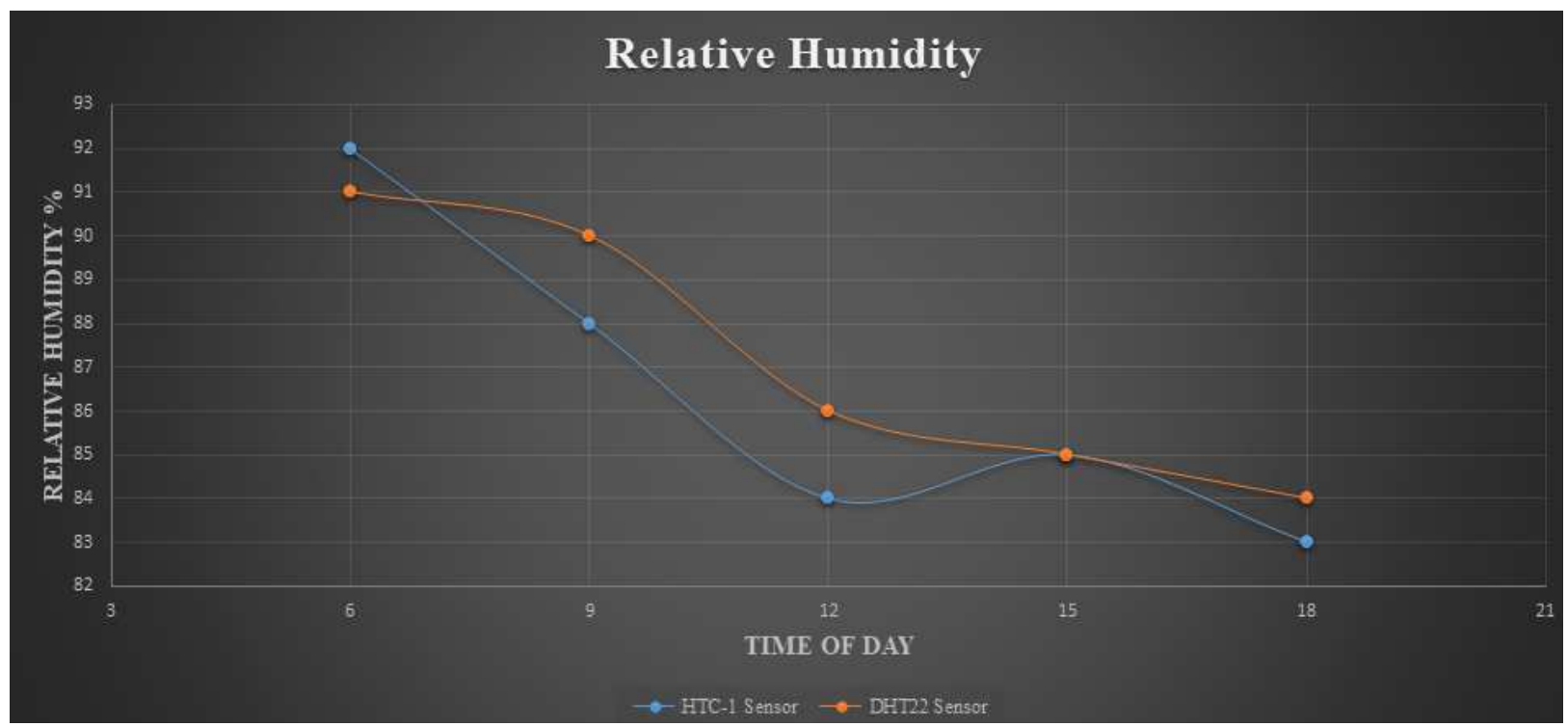

Figure 19: Comparison of humidity data with commercial sensor and sensor used in the application

With the collected data the average error was calculated, in the case of temperature it is $6.5 \%$ and in the case of relative humidity, it is $1.3 \%$, which are tolerable values taking into account that the ranges of these variables exposed by the reference documents allow the sensor not to be strictly accurate.

The data taken with the DHT 22 sensor was stored in the internal EEPROM memory of the PSoC5LP, this data was taken every three hours every day, even though in the reference texts it was advised to take one shot per day, this to have a good amount of data for the study. It coincided with the rainiest and most changing time of the year, so the breeding period of the birds had many inconveniences due to the sudden change in environmental conditions. Figure 20 presents the data collected on temperature for the 28-day breeding period.

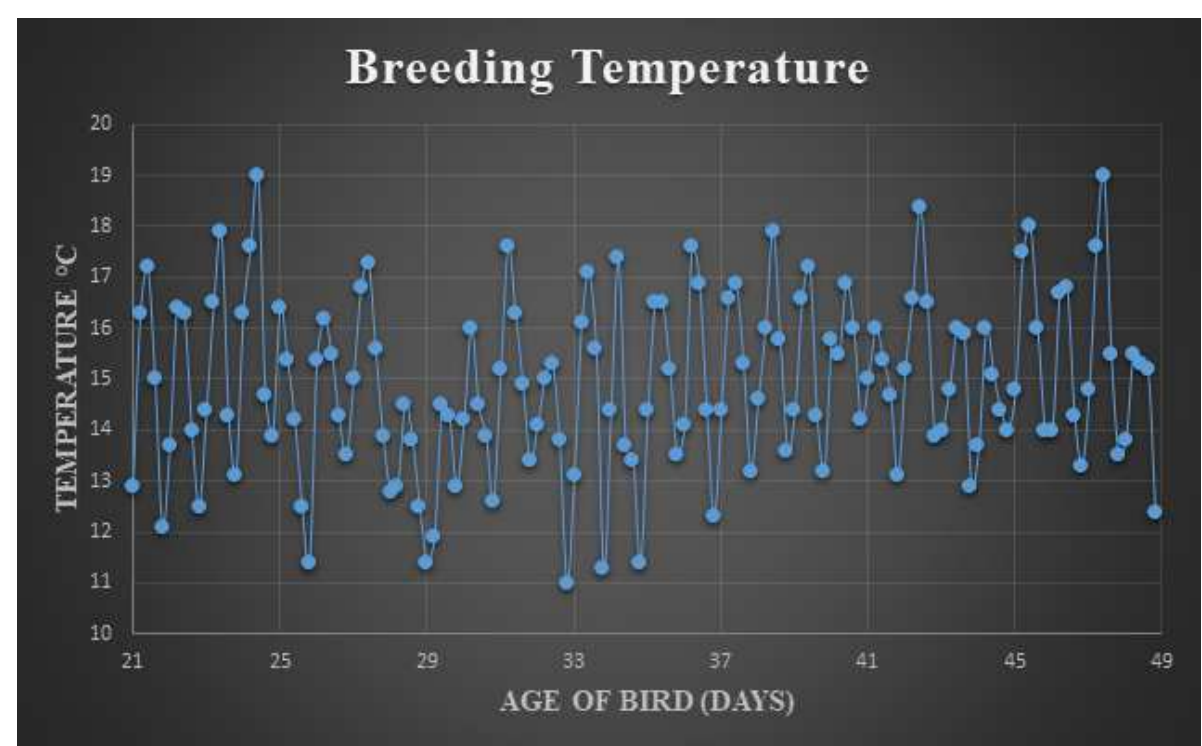

Figure 20: Temperature of rearing the birds in 28 days

Figure 21 shows the relative humidity data collected. It was determined, as expected, that one of the most significant drawbacks was the relative humidity due to the rainy season, for this reason, there are many relative humidity indexes close to $99 \%$, that is, critical environmental conditions for the bird, this occurred regularly in the early hours of the morning. Also, it was decided to change the soil protection layer in a short period, which resulted in a decrease in the relative 
humidity index in the last weeks, reaching $60 \%$. This index is closer than suggested by the reference text on environmental management in broiler houses [21].

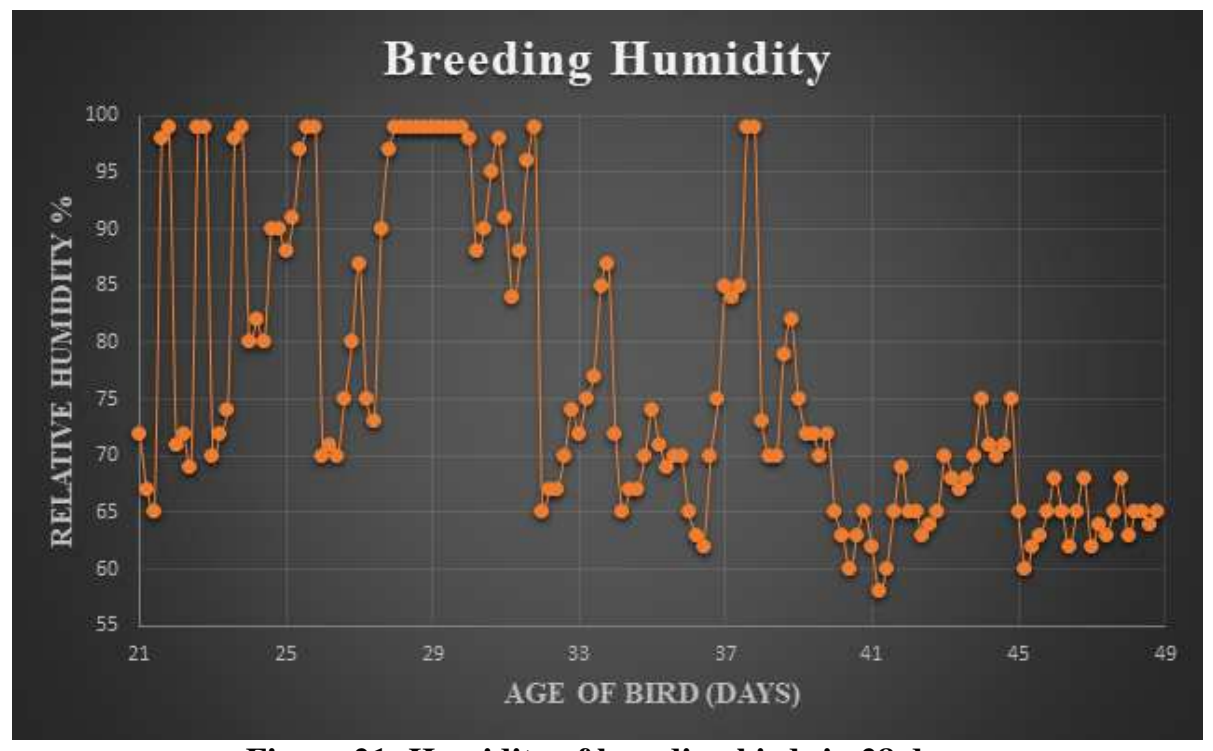

Figure 21: Humidity of breeding birds in 28 days

\subsection{Live Weight Monitoring}

Taking the weighing of the birds as a regular activity is one way to evaluate the performance of the flock and it is also the way to ensure that the characteristics intended for the final product are met or as close as possible. When poultry flocks were reared before implementing automation with embedded systems, certain results were achieved in terms of profitability, which became a benchmark for evaluating the performance of the growth of the birds already with the system in place. To correctly weigh the birds, the recommendations of the broiler management manual were taken [21].

The method used for the control of the birds was manual weighing since due to the density of the population it is the method that best applies. This activity was carried out once a week following the following recommendations:

- It was carried out once a week, at the same time of the day.

- A sample of 5 birds was taken, in each of the growth stages, which corresponds to $25 \%$ of the population density.

- We tried to capture and handle the birds without causing them any damage or stress.

Table 3 presents the weight data collected at each stage of bird growth. Based on these data, production rates are calculated to evaluate the performance of the flock. All of these rates were calculated with the data from the end of the rearing period, that is before the birds were slaughtered [23]. The production parameters that were taken into account were: Mortality (M \%), Feed Conversion (FC) and uniformity (VC \%).

Table 3: Weight data collected at each stage of bird growth

\begin{tabular}{|c|c|c|}
\hline AGE (Weeks) & $\begin{array}{l}\text { LIVE WEIGHT } \\
\text { (pounds) }\end{array}$ & $\begin{array}{l}\text { AVERAGE LIVE } \\
\text { WEIGHT (pounds) }\end{array}$ \\
\hline \multirow{5}{*}{ Arrival } & 2 & \multirow{5}{*}{ 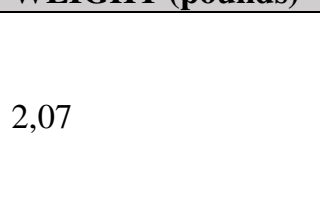 } \\
\hline & 2 & \\
\hline & 2 & \\
\hline & 2,25 & \\
\hline & 2,12 & \\
\hline 4 & 3 & 3.17 \\
\hline
\end{tabular}




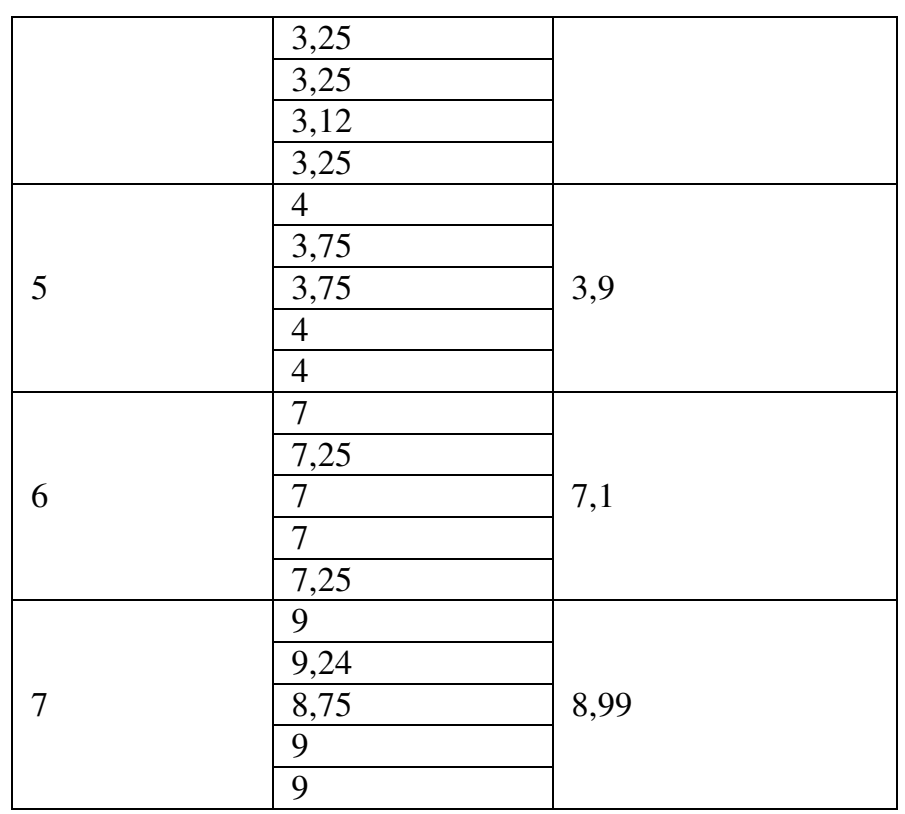

\subsubsection{Food Conversion}

In general, feed conversion is a measure of an animal's productivity and is defined as the relationship between the food it consumes and the weight it gains [23]. This relationship is an important factor in determining profitability in (1).

$F C=\frac{\text { Total food consumed }}{\text { Total live weight }}$

Where:

Total food consumed (FC) is determined by taking the total feed consumed per serving and calculating the feed consumed by the birds in a day, then calculating the total feed consumed in a week and finally calculating how much feed the five birds sampled at the time of weighing.

Total live weight (LW) is determined by adding the weights obtained from the sample of birds per week.

Table 4 shows the feed conversion values for each week of rearing the birds taking into account (1) the above descriptions and the information in Table 2.

Table 4: Feed conversion factor (FCD daily feed consumption, FCW weekly feed consumption)

\begin{tabular}{|l|l|l|l|l|l|}
\hline WEEK & $\begin{array}{l}\text { FCD } \\
\text { (pounds) }\end{array}$ & $\begin{array}{l}\text { FCW } \\
\text { (pounds) }\end{array}$ & $\begin{array}{l}\text { FCW5 BIRDS } \\
\text { (pounds) }\end{array}$ & $\begin{array}{l}\text { LW } \\
\text { (pounds) }\end{array}$ & FCA \\
\hline 4 & 7 & 49 & 12,25 & 15,85 & 0,772 \\
\hline 5 & 8,5 & 59,5 & 14,875 & 19,5 & 0,763 \\
\hline 6 & 9,75 & 68,25 & 17,0625 & 35,5 & 0,481 \\
\hline 7 & 11 & 77 & 19,25 & 44,95 & 0,428 \\
\hline
\end{tabular}

According to the broiler handling manual, the lower the FCA value, the greater the efficiency of the bird in converting the feed consumed into live body weight [21]. Therefore, the results are satisfactory, so it can be said that even though the environmental conditions were not the best, it was possible to provide the birds with an environment where the energy requirements for maintenance are low and the bird can use the food's energy to grow as much as possible. 


\subsubsection{Mortality}

It is expressed as a percentage and is calculated by dividing the number of dead birds by the number of birds initiated, this multiplied by one hundred as presented in (2). It is estimated that mortality should be at $4 \%$ during 42 weeks [23].

$M(\%)=\frac{\text { Number of dead birds }}{\text { Number of birds at the beginning }} * 100$

(2)

\subsubsection{Uniformity}

The variability of a population (flock) is described by the coefficient of variation (VC\%), which is the standard deviation of the weight of the population of five birds expressed in percentage terms over the mean [21]. The VC\% value of a variable flock is high, while that of a uniform flock is low. Equation (3) shows the described relationship.

$V C(\%)=\frac{\text { Standard deviation }}{\text { Average body weight }} * 100$

(3)

So then the coefficient of variation in the batch of birds is:

$V C=\frac{0,17}{8,99} * 100=1,92 \%$

With this result, the poultry flock can be categorized as a uniform. It is necessary to clarify that there was a mixed flock, i.e. males and females in the same house, so it is expected that the coefficient of variation will be higher compared to that of the sexed flocks, according to what is indicated in the broiler management manual [21].

\section{CONCLUSIONS}

With the results obtained, it is not possible to speak of total control over the physical variables of interest using the method of ventilation used, but it is possible to affirm by the state of health of the birds that other objectives of the ventilation were fulfilled, such as the reduction of bad odors and the renewal of air inside the poultry house that allows the reduction of the levels of toxic gases.

The automation of the systems that provide water and food, allowed to minimize the stress and tension of the bird, since the person in charge of the poultry house does not have to enter with the same frequency. This is positive for the birds since it avoids health problems and also allows the storekeeper to spend fewer hours of the day caring for the birds. It was also noticeable that the way these mechanisms were implemented prevented the massive waste of water and food.

Through the results obtained when evaluating the production rates, it can be stated that the bird was guaranteed an environment where the energy requirements for maintenance are low and the bird can use a great amount of energy from the food to grow.

Although the data was collected in a single poultry house, on a single batch of birds and during 30 days, it can be seen that the automation system of poultry plants with an embedded system for small producers is functional, it is a system that can be implemented at a low cost and also allows modifications to achieve better control of the behavior of physical variables within the poultry house.

\section{ACKNOWLEDGMENTS}


The authors would like to thank the Universidad Distrital Francisco José de Caldas and the LASER research group that supported the development and testing of the project.

\section{REFERENCES}

1. FENAVI. (2018). El Sector AvícolaLogróCrecimiento del 6,4\% en el 2017. Retrieved from: http://www.fenavi.org/index.php?option=com_content $\& v i e w=$ article $\& i d=3577: 2018-01-09-14-39$ -

02\&catid=454: comunicados-de-prensa \&Itemid $=1348$

2. ProducciónAvícola - WATTAgNet.com. (2018). Se automatizanmás las granjasavícolasen Colombia. Retrieved from: https://video.wattagnet.com/3k3/se-automatizan-mas-las-granjas-avicolas-en-colombia/

3. FAO. (2018). ProducciónpecuariaenAmérica Latina y el Caribe | Oficina Regional de la FAO para América Latina y el Caribe|Organización de las NacionesUnidas para la Alimentación y la Agricultura. Retrieved from: http://www.fao.org/americas/prioridades/produccion-pecuaria/es/

4. El SitioAvicola. (2017). TendenciasAvícolasMundiales 2016: Américarepresenta el 44 porciento de la producciónmundial de pollo. Retrieved from: http://www.elsitioavicola.com/articles/2866/tendencias-avacolas-mundiales-2016-amarica-representael-44-por-ciento-de-la-produccian-mundial-de-pollo/

5. Ndiweni, N. J. (2013). Prudentpoultryfarming as a source of livelihood and foodsecurity in a changingclimate: The case of Zhombecommunallands, Zimbabwe. International Journal of Scientific and ResearchPublications, 3(10). pp 1-5.

6. FENAVI, FONAV, Ministerio de Agricultura y Desarrollo Rural, Departamento Administrativo Nacional de Estadística (DANE). (2018). Primer Censo Nacional de Avicultura Industrial.

7. DatosAbiertos. (2020). Zonificación De Aptitud Para GranjasAvícolasComerciales. Retrieved from: https://www.datos.gov.co/Agricultura-y-Desarrollo-Rural/Zonificaci-n-De-Aptitud-Para-Granjas-Av-colas-Come/k98encfu/about

8. FENAVI. (2018). Registro de granjas. Retrieved from: https://fenavi.org/etiquetas/granjas-avicolas/

9. Engomix. (2016). Ventajas de lossistemasautomatizados de comedero y bebedero. Retrieved from: https://www.engormix.com/MA-avicultura/noticias/ventajas-sistemas-automatizados-comedero-t22254/p0.htm

10. Castagnola, J. L. (2010). Aplicación de tecnologíaengranjasavícolas para la seguridaden la producción. Universidad Católica de Córdoba, Facultad de CienciasAgropecuarias.

11. Impex. (2020). Sistemas de bebederos - Niples para aves. Retrieved from: https://www.impex.nl/es/aves/equipos-debebederos/niples-para-aves

12. Aviagen. (2009). Manejo del ambienteen el galpón de pollo de engorde. Retrieved from: http://es.aviagen.com/assets/Tech_Center/BB_Foreign_Language_Docs/Spanish_TechDocs/Aviagen-Manejo-AmbienteGalpn-Pollo-Engorde-2009.pdf

13. SizovaYu.V., Kucherenko, M. N., Vasilieva, L. A., Matveev, V.\&Kotin, A.I. (2020). Analysis of Microclimate in Livestock Housing. International Journal of Advanced Science and Technology. 29(3):3730-3736.

14. Aviagen. (2009). Guia de Manejo del Pollo de Engorde. Retrievedfrom: http://es.aviagen.com/assets/Tech_Center/BB_Foreign_Language_Docs/Spanish_TechDocs/smA-Acres-Guia-de-Manejo-delPollo-Engorde-2009.pdf

15. Villagómez, C. (2009). Avicultura-Pollos de engorde - Avipunta-Parámetrostécnicosrepresentativos para pollos de engorde. Retrieved

from: 
http://pollosengorde.blogspot.com/search/label/Densidad\%20poblacional\%20para\%20pollos\%20de\%20engorde

16. Camargo, J. \&Perdomo, C. (2016). Introducción al PSoC5LP: Teoría y aplicacionesprácticas. First ed., Bogotá: Ed. Universidad Distrital.

17. Camargo, J., Perdomo, C. \&Bermúdez, B. (2019). Proyectos prácticos con PSoC5LP.First ed., Bogotá: Ediciones de la U.

18. Solla - Nutrición animal. (2015). Manual de Manejo para Pollo de Engorde. Retrieved from: https://www.solla.com/sites/default/files/productos/secciones/adjuntos/Manual\%20De\%20Manejo\%20Para\%20Pollo\%20De \%20Engorde.pdf

19. Jha, B. K.\&Chakrabarti. A. (2017). Back Yard Poultry Farming as a Source of Livelihood in Tribal Village: An Economic Appraisal. International Journal of Agricultural Science and Research (IJASR). 7(1):267-274.

20. Kirkpatrick, $K$ \& Fleming, E. (2008). Aviagen - ROSS TECH 08/47: Calidad del agua. Retrieved from:http://es.aviagen.com/assets/Tech_Center/BB_Foreign_Language_Docs/Spanish_TechDocs/SPRossTechNoteWaterQual ity.pdf

21. Aviagen. (2014). Manual de Manejo del Pollo de Engorde ROSS. Retrieved from:http://eu.aviagen.com/assets/Tech_Center/BB_Foreign_Language_Docs/Spanish_TechDocs/RossBroilerHandbook2014ES.pdf

22. Tienda Tecnica.co. (2020). Termohigrómetro HTC-1 con Certificado de Calibración. Retrieved from:https://tiendatecnica.com.co/products/termohigrometro-htc-1-con-certificado-de-calibracion

23. Díaz, D. R., Rivero, D., Collante, J. \& Gonzalez, D. (2007). Evaluación productiva (IOR) en una granja de pollos de engorde del estado Trujillo de Venezuela con dos sistemas de producción (estudio de casos). Agricultura Andina. 12(1):55-65. 

